\title{
Strategi Komunikasi Verbal dan Nonverbal Guru terhadap Anak Didik Autis di Yayasan Tali Kasih Medan
}

\section{Verbal and Nonverbal Communication Strategy for Autistic Students at the Tali Kasih Foundation in Medan}

\author{
Trie Tifany Natasha Panggabean \\ Magister Ilmu Komunikasi, Fisip, Universitas Sumatera Utara,Indonesia \\ *Coresponding Email: tifanvtnp@gmail.com
}

Diterima: Maret 2019; Disetujui: April 2019; Dipublikasikan: April 2019

\begin{abstract}
Abstrak
Tulisan ini membahas strategi komunikasi verbal dan nonverbal guru terhadap anak didik autis di Yayasan Tali Kasih. Anak autis memiliki perilaku aneh yang terlihat tidak peduli dengan lingkungan sekitarnya dan cenderung menyendiri seakan-akan hidup dalam dunia yang berbeda. Perilaku ini terjadi karena adanya faktor kerusakan saraf di bagian otak yang mengakibatkan terjadi gangguan kemampuan sosial, emosi tidak stabil dan gangguan bicara. Yayasan Tali Kasih merupakan salah satu sekolah yang menyediakan jasa terapi untuk anak-anak autis. Tujuan penelitian ini adalah untuk menggambarkan strategi komunikasi verbal dan nonverbal guru terhadap anak didik autis di Yayasan Tali Kasih Serta memaparkan hambaran dalam mengajar anak autis.. Penelitian ini menggunakan metode penelitian deskriptif kualitatif dengan analisis komunikasi verbal dan nonverbal guru. Metode pengumpulan data didapat dengan observasi partisipan dan wawancara. Teknik penentuan informan secara purposive, informan utama dalam penelitian ini adalah guru-guru yang memiliki pengalaman mengajar minimal setahun di Yayasan Tali Kasih. Temuan penting yang dapat dilihat dari penelitian ini adalah strategi komunikasi verbal dan nonverbal guru berpengaruh terhadap penerimaan pesan materi program terhadap anak autis serta cara guru dalam menghadapi hambatan dalam mengajar anak autis menentukan hasil pengajaran yang berdampak pada perkembangannya.
\end{abstract}

Kata Kunci: Strategi Komunikasi, Komunikasi Verbal, Komunikasi Nonverbal, Anak Autis.

\begin{abstract}
This paper discusses the teacher's verbal and nonverbal communication strategies towards autistic students at the Tali Kasih Foundation. Autistic children have strange behaviors that don't seem to care about their surroundings and tend to be alone as if they live in a different world. This behavior occurs because of nerve damage in the part of the brain that results in impaired social abilities, unstable emotions and speech disorders. Tali Kasih Foundation is a school that provides therapeutic services for autistic children. The purpose of this study was to describe the teacher's verbal and nonverbal communication strategies towards autistic students at the Tali Kasih Foundation and to describe the scattering in teaching autistic children. This study used a descriptive qualitative research method with an analysis of teacher verbal and nonverbal communication. The method of data collection is obtained by participant observation and interviews. The technique of determining informants purposively, the main informants in this study were teachers who had teaching experience of at least a year at the Tali Kasih Foundation. An important finding that can be seen from this research is that the teacher's verbal and nonverbal communication strategies influence the acceptance of program material messages on autistic children and the way teachers deal with obstacles in teaching autistic children to determine the teaching outcomes that have an impact on their development.
\end{abstract}

Keywords: Communication Strategy, Verbal Communication, Nonverbal Communication, Autistic Children.

How to Cite: Panggabean. T.T.N (2019). Strategi Komunikasi Verbal dan Nonverbal Guru terhadap Anak Didik Autis di Yayasan Tali Kasih Medan. Jurnal Simbolika. 5 (1): 44-58 


\section{PENDAHULUAN}

Autis atau Autistic Spectrum Disorder (ASD) merupakan salah satu bentuk gangguan perkembangan yang mempengaruhi beberapa aspek, terkait bagaimana anak melihat dunia dan bagaimana belajar melalui pengalamannya. Autis sendiri biasa terjadi pada anak-anak dengan probabililitas potensi anak laki-laki terkena gejala autis empat kali lebih banyak dari anak perempuan (Cassandra, 1980) Anak autis biasanya memiliki keterbatasan dalam berkomunikasi dan tidak dapat berinteraksi dengan dunia luar secara efektif.

Anak autis memiliki perilaku aneh yang terlihat tidak peduli dengan lingkungan sekitarnya dan cenderung menyendiri seakan-akan hidup dalam dunia yang berbeda. Perilaku ini terjadi karena adanya faktor kerusakan saraf di bagian otak.

Penyandang autis mengalami gangguan kualitatif dalam interaksi sosial yang timbal balik, seperti tidak mampu menjalin interaksi sosial yang memadai karena adanya kontak mata yang kurang, ekpresi wajah yang kurang hidup, gerak gerik yang kurang tertuju, tidak dapat merasakan apa yang dirasakan orang lain, serta kurangnya hubungan sosial dan emosional yang timbal balik (Budyatna, M. \& Ganiem, 2011)

Anak autis juga mengalami gangguan kualitatif dalam bidang komunikasi seperti mengalami keterlambatan dalam berbicara atau bahkan kemampuan berbicara sama sekali tidak berkembang. Penderita autis juga sering menggunakan bahasa yang aneh dan diulang-ulang. Anak autis juga memiliki ciri khas dalam mempertahankan dan mengulang-ulang perilaku, minat dan kegiatan (Danuatmaja, 2003)

Menurut UNESCO yang merilis data terkait penyandang autis di dunia pada tahun 2011 tercatat terdapat 35 juta orang penyandang autis dari seluruh dunia. Artinya rata-rata 6 dari 1000 orang di dunia mengidap autis. Selanjutnya, menurut data 2014 dari Pemerintah Amerika Serikat, di negara tersebut terdapat 1.5 persen anak-anak autis atau satu dari 68 anak menderita autisme. Sementara itu di Inggris, terdapat sebanyak 1,1 persen penduduk di atas 18 tahun yang menderita autis. Di Indonesia sendiri meski belum ada survei resmi mengenai jumlah anak autis di Indonesia, namun pada tahun 2013 lalu Direktur Bina Kesehatan Jiwa Kementerian Kesehatan menduga jumlah anak penderita autis mencapai 112.000 orang dalam rentang umur 5-19 tahun (cnnindonesia.com). 
Menurut jurnal indonesia.net, tahun 2015 di Indonesia diperkirakan satu dari 250 anak mengalami gangguan autisme dan diperkirakan terdapat kurang lebih 12.800 anak penyandang autisme dan 134.000 penyandang spektrum autis. Pendataan yang dilakukan oleh Forum Masyarakat Peduli Autis (FMPA) pada tahun 2012, jumlah anak autis di Sumatera Utara berkisar 1000 orang, dimana jumlah anak autis yang lahir di Kota Medan diperkirakan telah mencapai 250 anak pertahun dan jumlahnya akan terus bertambah.

Lebih lanjut, Indonesia telah meratifikasinya melalui UU No. 19 Tahun 2011 (UU Disabilitas) dan UU No. 39 Tahun 1999 tentang Hak Asasi Manusia (UU HAM). Autis termasuk kelompok masyarakat rentan (vulnerable group) yang dilindungi hak asasinya. Aturan hukum tersebut memberikan hak keadilan dan perlindungan hukum kepada anakanak autis, termasuk hak atas perlakuan yang sama di hadapan hukum. Aturan hukum tersebut juga mewajibkan pemerintah, pemerintah daerah, dan lembaga negara lainnya untuk bertanggung jawab dengan memberikan perlindungan khusus kepada anak, termasuk anak korban kekerasan fisik dan/atau psikis dan anak penyandang disabilitas, tak terkecuali anak dengan autisme (detik.com).

Perlindungan khusus bagi anak tersebut di atas dapat dilakukan melalui beberapa upaya, salah satunya dengan menyediakan bantuan hukum kepada anak autis dalam setiap pemeriksaan pidana pada setiap lembaga penegak hukum sesuai dengan Kitab Undang-Undang Hukum Acara Pidana

Setiap penderita autis memiliki karakteristik yang berbeda-beda. Adapun gejala autis yang tampak pada umumnya adalah anak autis biasanya tidak memiliki kontak mata, cenderung menghindar saat melihat interaksi sosial, sangat selektif terhadap rangsangan seperti tidak suka dipeluk, serta melakukan gerakan yang berulang-ulang, seperti menggoyangkan tubuh atau jari.

Sekalipun anak autis memiliki keterbatasan dalam interaksi sosial dan komunikasi, namun menurut penelitian yang dilakukan di Inggris, sebagian anak autis memiliki karakteristik lebih kreatif dalam menginterpretasikan gambargambar tertentu. Anak autis juga memiliki kemampuan visual yang berkembang dengan sangat baik, sehingga rata-rata anak autis memiliki kemampuan memori visual yang sangat baik dalam mengingat gambar visual. 
Selain itu terdapat sebuah penelitian yang menemukan bahwa bobot otak anak autis cenderung lebih besar daripada anak-anak normal dan memiliki sel saraf 79\% lebih banyak. Untuk itu ada beberapa kasus dimana banyak penderita autis yang memiliki keistimewaan khusus seperti tingkat intelegensia yang tinggi dan kemampuan penalaran di luar kemampuan rata-rata manusia dewasa. Kategori penderita autis seperti ini dikenal sebagai sindrom Asperger. Namun, anak autis yang memiliki IQ yang tinggi, biasanya tidak sebanding dengan kecerdasan emosional (EQ) dan Spritual Quotient (SQ) / kecerdasan spiritual yang dimilikinya (klinikautis.com).

Contoh kasus autis sindrom Asperger dialami oleh Jacob Barnett, seorang anak autis berumur 12 Tahun di Amerika yang dapat memecahkan teori Big Bang (teori konsep rumusan matematika yang sangat rumit) dan memiliki kemampuan IQ yang melebihi Albert Einsten (170). Jacob awalnya tidak dapat mengucapkan sepatah katapun hingga menginjak usia dua tahun. Keistimewaan yang dimiliki Jacob tersebut kemudia menjadikannya sebagai pengajar di Universitas Indiana dengan mengajar hal-hal yang berhubungan dengan dunia matematika (merdeka.com).

Para penyandang autis yang memiliki keterbatasan dan kemampuan berbeda- beda, membutuhkan bantuan dari orang lain dalam mengembangkan diri. Dengan pendampingan dan penanganan yang tepat, anak autis dapat ditarik dari dunianya sehingga bisa hidup bersosialisasi dengan orang lain dan menjadi makhluk sosial yang baik (Marijani, 2003)

Indonesia sendiri telah memiliki banyak sekolah terapi untuk anak-anak berkebutuhan khusus, seperti anak autis. Kebanyakan sekolah terapi khusus untuk anak autis terpusat di Jakarta dan dengan menawarkan opsi metode terapi yang beragam. Namun bila dibandingkan dengan kota Medan, sekolah terapi untuk anak autis masih tergolong sedikit. Dua diantara sekolah yang menyediakan jasa terapi bagi anak autis dan yang memiliki reputasi yang cukup terkenal di Kota Medan adalah Yayasan Tali Kasih.

Yayasan Tali Kasih adalah sekolah autis pertama yang ada di Kota Medan. Lembaga ini merupakan lembaga pendidikan untuk anak berkebutuhan khusus yang didirikan pada tahun 2000 oleh Bapak Sahid Hamid dan Bapak B. Saragih. Berawal dari kepelian mereka yang melihat pada saat dahulu belum ada sekolah pendidikan khusus bagi anak autis di Kota Medan, mereka pun mendirikan pertama kali Yayasan Tali Kasih ini di jalan K.H.Wahid Hasyim. Satu tahun kemudian 
Yayasan Tali Kasih dibuka di jalan Sei Alas no 18. Hingga saat ini Yayasan Tali Kasih menjadi sekolah terapi anak autis yang diperhitungkan di kota Medan.

Yayasan Tali Kasih memiliki visi dan misi dalam menentukan arah dan dapat mencapai tujuan yang diharapkan. Visinya adalah memberian harapan kepada orang tua dan memberikan harapan bagi masa depan anak. Sedangkan misinya adalah untuk menyelenggarakan pendidikan yang bermutu untuk menolong orang tua yang mempunyai anak autis dan anak berkebutuhan khusus lainnya dalam meraih masa depannya.

Pemilihan lokasi penelitian di Yayasan Tali Kasih didasarkan pada alasan bahwa kedua lembaga ini memiliki reputasi sekolah yang baik dan telah dikenal berpengalaman dalam menyelenggarakan program terapi bagi anak autis. Pada dasarnya kurikulum di sekolah autis tidak sama dengan sekolah umum. Umumnya kurikulum pendidikan yang diajarkan sangat bersifat individual. Adapun penentuan pembelajaran untuk anak autis berpedoman pada Badan Standar Nasional Pendidikan (BSNP).

Meskipun demikian, Departemen Pendidikan Nasional memberikan keleluasaan bagi setiap sekolah khusus autis dalam menentukan kurikulum. Hal ini dikarenakan oleh kebutuhan yang berbeda-beda dari setiap sekolah dalam mendidik anak autis. Kurikulum harus dibuat berbeda untuk masing-masing individu anak autis yang memiliki kebutuhan yang berbeda-beda pula (Meranti, 2017)

Yayasan Tali Kasih menerapkan metode terapi ABA (Applied Behavioral Analysis) kepada anak didik autisnya. Terapi ABA ini sendiri merupakan terapi yang paling banyak digunakan di Indonesia. Terapi ini dinilai dapat dengan efektif meningkatkan keterampilan anak dalam mengelola perilaku mereka, merawat diri dan berinteraksi.

Sebelum penerapan terapi ini pada anak, lazimnya pihak lembaga atau sekolah akan melakukan observasi terhadap anak disertai dengan konsultasi dengan orang tua. Observasi tersebut dilakukan untuk melihat karakteristik anak, kelemahan maupun kelebihan yang dimilikinya. Dari hasil observasi dan konsultasi tersebut, kemudian akan disusunlah materi program yang sesuai dengan kebutuhan anak autis tersebut.

Guru kemudian akan menjalankan materi program yang telah dirancang sesuai dengan kebutuhan anak didik autisnya. Proses pembelajaran biasanya berlangsung dengan komunikasi antarpribadi di dalam satu ruangan kelas. Pada ruang kelas tersebut guru dan anak 
duduk saling berhadapan sehingga diharapkan komunikasi dapat berjalan lebih efektif.

Komunikasi antarpribadi adalah komunikasi antara orang-orang yang dilakukan secara tatap muka dan memungkinkan setiap pesertanya menangkap reaksi verbal maupun nonverbal (Mulyana, 2008). Salah satu bentuk komunikasi antarpribadi adalah komunikasi diadik yang melibatkan antara dua orang saja. Komunikasi antarpribadi lazim digunakan antara guru dan anak didiknya. Komunikasi antarpribadi dalam proses mengajar anak autis dinilai lebih efektif dan memberikan dampak.

Mendidik anak autis merupakan hal yang tidak mudah dan memiliki tantangan tersendiri bagi guru. Salah satu tantangan yang dihadapi para guru ketika pertama kali bertemu dengan anak didik autis adalah bagaimana membangun hubungan antarpribadi yang baik dengan anak dan bagaimana dapat menciptakan pola komunikasi yang tepat kepada anak. Pendekatan secara antarpribadi ini akan berpengaruh pada proses penerimaan anak autis untuk materi program yang diajarkan.

Tantangan lainnya adalah guru harus menghadapi keterbatasan anak autis yang memiliki gangguan dalam berinteraksi sosial dan berkomunikasi. Masalah utama yang menjadi fokus terapi pada anak autis adalah masalah komunikasi dan interaksi. Guru harus menemukan cara yang tepat dalam menghadapi tantangan dalam berkomunikasi dengan anak autis sehingga anak dapat menerima materi program dan mengalami perkembangan dalam berkomunikasi dan berinteraksi dengan lingkungan sekitarnya.

Guru pengajar anak autis tidak hanya membutuhkan kesabaran tetapi juga strategi dalam berkomunikasi dengan anak autis. Strategi komunikasi tersebut bisa secara komunikasi verbal maupun nonverbal. Komunikasi verbal tidak lepas dari proses mengajar guru dimana guru tentu menyampaikan pesan-pesan verbal pengajaran kepada anak.

Sedangkan untuk menguatkan materi yang disampaikan secara verbal, guru tentu melakukan komunikasi nonverbal dengan melakukan berbagai gerakan isyarat, sentuhan, ekspresi wajah ataupun postur tubuh yang mendukung. Maka penelitian ini akan meneliti strategi komunikasi verbal dan nonverbal guru terhadap anak didik autis dalam konteks komunikasi antarpribadi dengan mengambil subjek penelitian guru-guru dari Yayasan Tali Kasih 


\section{METODE PENELITIAN}

Metode penelitian ini adalah kualitatif dengan

konstruktivisme. paradigma Paradigma

konstruktivisme merupakan paradigma yang hampir merupakan antithesis dari paham yang menjadikan pengamatan dan objektivitas dalam menemukan realitas atau ilmu pengetahuan. Paradigma ini juga memandang ilmu sosial sebagai suatu analisis yang sistematis terhadap socially meaningful action melalui pengamatan langsung dan terperinci terhadap pelaku social yang bersangkutan, dan menciptakan serta memelihara ataupun mengelola dunia social mereka (Hidayat, 2003)

Metode kualitatif berkembang mengikuti suatu dalil sebagai proses yang tidak pernah berhenti (unfinished process). Ia berkembang dari proses pencarian dan penangkapan makna yang diberikan oleh suatu realitas dan fenomena sosial. Berdasarkan sifat realitas, metode kualitatif mengandung persepsi subjektif bahwa realitas (komunikasi) bersifat ganda, rumit, semu, dinamis (mudah berubah), dikonstruksikan dan holistik; kebenaran realitas bersifat relatif (Hikmat, 2011)

Metode yang dipilih dengan melakukan observasi langsung ke Yayasan Tali Kasih Medan dengan proses pengamatan langsung, wawancara, jurnal dan buku-buku. Penentuan informan sebagai sumber data dalam penelitian ini ditentukan pada subjek penelitian yang mempunyai pengetahuan dan pengelaman yang dibutuhkan peneliti sesuai dengan permasalahan penelitian, mampu mengemukakan pengetahuan dan pengalamannya dan mempunyai waktu untuk diwawancarai untuk keperluan penelitian.

Data dikumpulkan dimulai saat observasi awal, pra penelitian hingga wawacara langsung kepada informan di sekolah. Saat melakukan wawancara, peneliti menggunakan alat tulis dan catatan untuk mencatat hal-hal penting yang disampaikan oleh informan dan didukung dengan alat perekam berupa kamera digital, kamera ponsel dan alat perekam suara ponsel agar memudahkan peneliti dalam mengumpulkan data secara penuh.

Penelitian ini dimulai dari bulan Februari 2018 sampai dengan September 2018. Penelitian ini menggunakan metode penelitian kualitatif yang akan menghasilkan data deskriptif berupa katakata tertulis secara lisan berdasarkan perilaku yang diamati. Pendekatan yang dilakukan mengarah pada pengalaman mengajar guru di sekolah yang diamati secara langsung oleh peneliti, lalu akan 
dideskripsikan secara tertulis. Tahap analisis yang dilakukan adalah membuat daftar pertanyaan untuk wawancara, pengumpulan data dan analisis data yang dilakukan sendiri oleh peneliti sehingga kemudian didapat kedalaman informasi yang diberikan informan peneltian.

Berikut beberapa rincian tahap penelitian yang dilakukan yaitu (a)Peneliti menyusun daftar pertanyaan wawancara yang ditujukan kepada informan, yang pertanyaannya telah disesuaikan dengan fokus masalah dan tujuan penelitian ini. (b)Peneliti melakukan wawancara dengan beberapa guru di Yayasan Tali Kasih hingga didapatkan data yang lengap. (c)Peneliti mengamati secara langsung setiap proses mengajar guru di dalam satu ruangan bersamaan dengan guru dan murid. (d)Peneliti kemudian memindahkan semua temuan data penelitian yang didapat dari hasil dari wawancara dan observasi atas informan. (e) Peneliti menganalisis data dari hasil wawancara dan observasi untuk penelitian ini.

\section{HASIL DAN PEMBAHASAN}

\section{Strategi Komunikasi Verbal}

Secara substansi komunikasi verbal merupakan bentuk komunikasi yang disampaikan komunikator kepada komunikan dengan cara tertulis (written) atau lisan (oral) untuk tujuan dalam mengungkap ide-ide, pemikiran atau keputusan, mudah disampaikan secara verbal ketimbang non verbal. Setiap metode pengajaran di Yayasan Tali Kasih seperti menulis angka, menggambar dan membaca.

Artinya setiap materi program pengajaran di Yayasan Tali kasih dirancangkan kepada anak autis tentu memiliki tujuan bagi perkembangan anak yang salah satunya melipat origami. Tujuannya untuk melatih motorik halus agar ada keseimbangan koordinasi antara mata dengan tangan, serta memberikan keluwesan pada otot tangannya. Hal tersebut juga membutuhkan konsentrasi, sehinggga lewat program melipat origami tersebut dapat melatih fokus dan kesabaran pada anak didik autis.

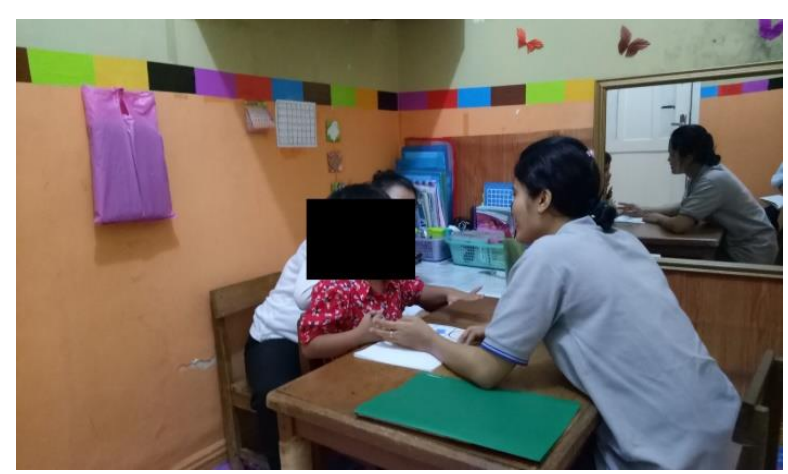

Gambar 1. Komunikasi Verbal

Setiap pertemuan belajar mengajar di Yayasan Tali Kasih, anak akan menerima pengajaran dari guru selama 2 jam lamanya. Setiap harinya kelas di Yayasan 
Tali kasih memiliki sesi mengajar yaitu pada pukul 8 pagi, 10 pagi, 1 siang dan 3 sore. Sebelum kegiatan belajar dimulai setiap sesinya, anak didik autis melakukan gerakan pemanasan di ruang tengah sekolah dengan menggunakan musik senam selama sepuluh menit. Kegiatan pemanasan tersebut selalu dipandu oleh satu guru di depan anak-anak, dan asisten guru dibelakang anak-anak didik autis.

Menurut salah satu guru di Yayasan Tali Kasih Roma yang mengatakan Strategi komunikasi verbal yang diterapkan di Yayasan Tali Kasih kepada anak didiknya adalah dengan cara menirukan dengan tujuan melatih motorik. Hal tersebut dijelaskan lebih lanjut dalam wawancaranya dengan peneliti.

"Kalau verbalnya itu tadilah, langkahnya harus menirukan itu tadi dulu, gitu loh. Motoriknya itu harus tercapai, kalau dia ga bisa menghisap, kalau dia ga bisa meniup, gimana dia? Berartikan ada yang ga berfungsi kan.

Itu dulu yang kita kerjakan, menjulurkan lidah, kaya mana nanti dia bisa membentuk huruf el el gitu, jadi kita harus itu dulu pertama. Menirukan itu dulu, motorik mulut itu, baru kita masuk ke speak therapy. Speak therapynya pun huruf-huruf vokal dulu, seperti A, I, U, E, O. Baru nanti ke abjad-abjad. Baru dipanggil- panggillah, panggil apa dia jawab apa gitu kan."

Sementara Guru Lainnya, Nia mengajarkan anak tersebut untuk menjulurkan lidah dan menginstruksikan anak untuk menirukan gerak bibir dan suara huruf. Ketika anak berhasil melewati program tersebut, anak tersebut akan diajarkan speak therapy.

Pengajaran speak therapy, dilakukan dengan mengajarkan cara mengucapkan huruf-huruf vokal seperti A, I, U, E, O. Apabila anak berhasil mengucapkan huruf vokal, lalu ia akan diajarkan pula bagaimana mengucap huruf abjad lainnya. Kemudian anak akan diajarkan beberapa kalimat singkat dalam bentuk pertanyaan dan bagaimana anak tersebut harus menjawab. Nia menjelaskan strategi komunikasi dengan anak autis lebih efektif dilakukan dengan cara verbal. Nia menjelaskan lebih lanjut perihal tersebut lewat wawancara dengan peneliti.

"Kalau itu menurut saya rasa lebih ke verbalnya sih, mereka itu lebih mudah diajari. Apalagi kalau memang dia autis yang aktif, jauh lebih enak sih ngajarinya. Kenapa? Karena saya rasa anak autis aktif itu lebih cepat kayanya untuk menirukan verbalnya, dibanding yang pasif itu tadi"

Nia memaparkan bahwa anak autis lebih mampu menangkap materi program dengan komunikasi verbal dalam bentuk 
pemberian instruksi. Terlebih untuk anak autis yang aktif, anak autis ini dinilai Nia lebih cepat dalam menirukan kata-kata verbal yang diucapkan guru.

\section{Komunikasi NonVerbal}

Yayasan Tali Kasih menggunakan metode ABA (Applied Behavior Analysis). Dapat diartikan pula Terapi ABA (Applied Behavior Analysis) adalah bentuk modifikasi perilaku dengan melakukan pendekatan secara langsung dan berfokus pada perubahan secara spesifik, dapat berupa perubahan dalam interaksi sosial, bahasa atau perawatan diri sendiri (Mirna, 2004).

Metode ABA ini bertujuan untuk mengajarkan kepada anak bagaimana cara berkomunikasi dua arah yang aktif, bagaimana bersosialisasi dengan lingkungan sekitarnya dan menghilangkan atau meminimalisir perilaku yang tidak wajar serta memberikan pengajaran kemampuan akademik dan kemandirian. Efektifitas dari terapi ini adalah kemampuan dalam memperbaiki kepatuhan, tanggung jawab, kemandirian, disiplin dan hubungan keluarga.

Mengikuti prinsip pelaksanaan terapi ABA (Applied Behavior Analysis), Yayasan Tali Kasih mengikuti langkah awal dalam memulai terapi ini kepada anak autis, yaitu dengan memutuskan terlebih dahulu materi program apa yang cocok dengan anak. Anak autis yang telah diobservasi sebelumnya dan dikumpulkan informasinya melalui orang tuanya, kemudian dirancang program sesuai dengan kemampuan anak autis tersebut.

Program awal dari ABA (Applied Behavior Analysis) yang diterapkan di Yayasan Tali Kasih meliputi program kesiapan dalam belajar (berespon terhadap nama), program bahasa reseptif (mengikuti perintah satu tahap), program meniru (meniru program motorik kasar), program bahasa ekspresif (menunjuk benda-benda yang diinginkan), tugas menyamakan (menyamakan benda-benda yang identik), kemampuan pre-akademik dan kemandirian. Metode ini diajarkan secara sistematis, terstruktur dan terukur.

Ketika anak didik autis telah mencapai kemajuan pada program yang telah dirancangkan kepadanya, maka program baru pun akan di tambahkan. Setiap programnya diajarkan dengan cara bertahap sehingga anak memperoleh keterampilan sesuai dengan tujuan program tersebut (Trisnad, 2011).

Program bulanan yang dilaksanakan Yayasan Tali Kasih kepada seluruh siswanya yaitu kegiatan outdoor (luar ruangan) berupa kegiatan berenang, berbelanja di supermarket, berolahraga di taman umum, berkebun dan komputer serta kerajinan tangan. Setiap bulannya 
dipilih salah satu kegiatan outdoor oleh pihak Yayasan. Dalam pelaksanaan kegiatan outdoor ini, dilaksanakan selama dua hari disetiap bulannya. Setiap kegiatan luar ruangan guru akan mendampingi setiap anak didiknya.

Yayasan Tali Kasih memiliki ruang belajar sebanyak delapan ruang kelas dan satu ruang bermain. Di setiap ruang kelas terdapat satu meja belajar, dua sampai tiga kursi belajar, papan tulis dan buku-buku, alat tulis serta media visual seperti flashcard.Sistem mengajar yang dilakukan Yayasan Tali Kasih adalah satu guru dan satu anak, dimana guru dan anak akan duduk berhadap-hadapan dalam jarak yang sangat dekat. Bagi anak-anak autis yang dirasa masih butuh pendampingan lebih (biasanya anak yang masih baru dan anak autis yang pasif), maka asisten guru akan turut mendampingi dibelakang anak autis saat kegiatan belajar mengajar. Adapun media belajar yang digunakan untuk mengajar anak autis yaitu flashcard atau kartu bergambar (hewan, buah, warna, bentuk).

Analisis data dalam penelitian kualitatif merupakan tahap untuk menelaah data yang telah diperoleh dari beberapa informan yang telah dipilih selama penelitian berlangsung. Selain itu analisis data berguna untuk menjelaskan dan memastikan kebenaran temuan penelitian. Analisis data ini telah dilakukan sejak awal dan bersamaan dengan proses pengumpulan data di lapangan (Handoyo, 2014)

Pertemuan pertama untuk mengobservasi kelas salah satu pengajar Yayasan Tali kasih yaitub Endang yang berlangsung pada hari Kamis tanggal 8 Februari 2018 pukul 08.40 pagi. Pada saat itu Endang sedang mengajar Jolin, anak didik autis satu-satunya yang ia ajari pada saat itu. Endang sendiri merupakan kepala terapis di Yayasan Tali Kasih. Endang mempersilahkan peneliti untuk masuk ke dalam ruangan kelas dan menempatkan peneliti untuk duduk di belakang Jolin.

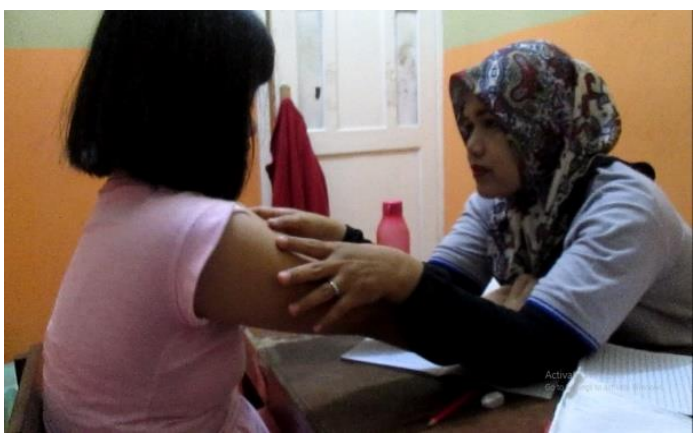

Gambar 2 Komunikasi Nonverbal Endang

Setiap anak didiknya memiliki materi program yang berbeda satu sama lain, disesuaikan dengan kebutuhan anak. Materi program rata-rata mengajarkan tentang kemandirian, regulasi diri dan social manner dan kemampuan akademik. Materi program kemandirian yang diajarkan seperti bagaimana cara untuk makan, berpakaian dan cara ke toilet. 
Materi social manner diajarkan dengan memperkenalkan aturan-aturan di tempat umum, kegiatannya seperti pergi ke bank ataupun supermarket. Selain itu kegiatan rutin untuk melatih fisik anak didik autis dengan mengajarkan yoga dan berenang. Sedangkan untuk materi akademik yang diajarkan, berupa pelajaran membaca dan berhitung, yang apabila anak didik sudah memahaminya, akan ditingkatkan ke pelajaran Bahasa Indonesia, Matematika, Bahasa Inggris, IPA, IPS dan lainnya.

Kesulitan yang sering Eva hadapi dalam proses mengajar anak autis adalah ketika anak didiknya sedang tidak mood dan perilakunya menunjukkan emosi yang tidak terkontrol atau tempramental, serta diikuti dengan tantrum. Dalam menghadapi tantrum anak didik autisnya, Eva biasa akan menghentikan kegiatan mengajar materi dan memberi instruksi anak didiknya tersebut untuk beristirahat sejenak. Hal tersebut dilakukannya sampai anak menunjukkan ketenangan.

Ketika melakukan pengamatan sewaktu Eva mengajar dengan salah satu anak didiknya, anak didiknya tersebut sejak dari awal sudah kelihatan sedang tidak mood. Terlihat beberapa kali ketika Eva memberi instruksi anak didiknya tersebut untuk membaca, namun anak tersebut terlihat matanya tidak fokus dan melakukan stimming dengan mengerakgerakkan badannya ke depan dan belakang.

Berulang kali pula Eva memegang tangan anak didiknya tersebut dan menggunakan intonasi yang tegas agar mengikuti instruksinya. Namun anak tersebut tampak semakin marah, dengan memukul-mukul meja belajarnya. Eva yang melihat emosi anak yang semakin memuncak, ia pun menutup buku bacaan dan memberi instruksi bagi anak untuk menjauhkan kursinya dari meja.

Ketika anak tidak melakukan instruksinya dan semakin terlihat tantrumnya dengan berteriak, Eva pun menarik tangan anak tersebut dan menyuruh anak tersebut minum lalu berbaring diatas tikar. Eva membantuk anak dengan menutup mata anak tersebut agar anak tersebut bisa beristirahat sebentar.

Ada kalanya selama tujuh tahun pengalamannya mengajar anak autis membawanya kepada perasaan putus asa ketika tidak kunjung melihat perkembangan anak didiknya. Eva menjelaskan caranya dalam mengatasi dan melakukan sharing tentang kesulitan yang dialami serta kesulitan anak yang dihadapinya dengan rekan kerja dan pembina di membantu Eva dalam mengatasi hambatannya dalam 
mengajar.Menurut Eva terdapat faktor pendukung keberhasilan proses belajar mengajar anak didik autis.

“Ada, faktor pendukungnya ya kerjasama dengan orangtua atau pihak keluarga anak sama lingkungan sekitarnyalah, biar perkembangan si anak itu pun bisa maksimal."

Dukungan dan kerjasama keluarga di rumah merupakan faktor pendukung utama dalam menentukan keberhasilan program pengajaran dan perkembangan anak. Ketika orang tua turut mengulang materi pengajaran di rumah atau memberikan bimbingan dan kasih sayang kepada anak, hal tersebut akan berpengaruh langsung terhadap perkembagan anak (Kuarniawan, 2009)

\section{SIMPULAN}

Adapun kesimpulan yang dapat di ambil dari penelitian ini adalah Strategi komunikasi verbal yang diterapkan di Yayasan Tali Kasih kepada anak didiknya adalah dengan cara menirukan dengan tujuan melatih motoric untuk tujuan dalam mengungkap ide-ide, pemikiran atau keputusan, mudah disampaikan secara verbal dipengajaran di Yayasan Tali Kasih seperti menulis angka, menggambar dan membaca.

Artinya setiap materi program pengajaran di Yayasan Tali kasih dirancangkan kepada anak autis tentu memiliki tujuan bagi perkembangan anak yang salah satunya melipat origami. Tujuannya untuk melatih motorik halus agar ada keseimbangan koordinasi antara mata dengan tangan, serta memberikan keluwesan pada otot tangannya dalam menulis dan menggambar. Selanjutnya strategi melipat gambar yang juga membutuhkan konsentrasi, sehinggga lewat program melipat origami tersebut dapat melatih fokus dan kesabaran pada anak didik autis.

Sementara untuk strategi nonverbal Yayasan Tali kasih menerapkan Metode ABA ini bertujuan untuk mengajarkan kepada anak bagaimana cara berkomunikasi dua arah yang aktif, bagaimana bersosialisasi dengan lingkungan sekitarnya dan menghilangkan atau meminimalisir perilaku yang tidak wajar serta memberikan pengajaran kemampuan akademik dan kemandirian. Efektifitas dari terapi ini adalah kemampuan dalam memperbaiki kepatuhan, tanggung jawab, kemandirian, disiplin dan hubungan keluarga.

Mengikuti prinsip pelaksanaan terapi ABA (Applied Behavior Analysis), Yayasan Tali Kasih mengikuti langkah awal dalam memulai terapi ini kepada anak autis, yaitu dengan memutuskan terlebih dahulu materi program apa yang cocok dengan 
anak. Anak autis yang telah diobservasi sebelumnya dan dikumpulkan informasinya melalui orang tuanya, kemudian dirancang program sesuai dengan kemampuan anak autis tersebut. Program ini meliputi kesiapan dalam belajar mengikuti perintah satu tahap, bahasa ekspresif, tugas menyamakan benda-benda yang identic.

Hambatan utama yang ditemui guruguru baik di Yayasan Tali Kasih Medan saat mengajar anak didik autis adalah ketika anak sering tidak fokus, emosi sedang tidak tidak stabil dan tantrum. Dalam menghadapi hambatan anak yang kehilangan fokus dalam belajar dan berkomunikasi, guru akan melakukan memanggil-manggil nama anak dan menyentuh wajah anak dan mengarahkannya. Ketika anak tidak memberikan respon, guru akan memberikan reward (penghargaan) dan punishment (hukuman) kepada anak. Penghargaan dapat berupa pujian atau pemberian benda atau makanan kesukaan anak. Sedangkan hukuman dapat diberikan guru dengan cara melarang atau menegaskan suara. Selain itu ketika anak menunjukkan emosi yang tidak stabil dan tantrum, guru melakukan tindakan menghentikan kegiatan mengajar dan mendiamkan anak hingga anak terlihat tenang. Setelah itu guru akan memberikan materi program yang disenangi anak setelah anak terlihat lebih tenang. Hambatan yang muncul dari luar diri anak autis, yaitu ketidakpedulian orang tua dan tidak adanya kerja sama dari orang tua dalam mendidik anak autis. Guru-guru menilai hal tersebut dapat berpengaruh buruk terhadap perkembangan anak autis, terutama dari segi emosionalnya.

Guru beranggapan bahwa dengan adanya dukungan kasih sayang dan kerja sama orang tua yang turut mengajari anak autis di rumah, dapat berpengaruh memajukan perkembangan anak autis itu sendiri dan anak autis dapat lebih mudah diajari di kelas. Guru-guru biasanya akan berkonsultasi dengan orang tua, memberi tahu perkembangan anak dan memberikan saran dan masukan yang berguna bagi orang tua terkait peningkatan perkembangan anak.

\section{UCAPAN TERIMAKASIH}

Ucapan hormat dan terima kasih yang terdalam saya persembahkan kepada kedua orang tua, ibu saya Prof.Dr.Sondang Manik, M.Hum dan ayah saya Tumpal Victor Panggabean, SH., MH. yang tercinta, telah banyak memberikan dukungan baik materi, moral dan doa selama saya perkuliahan hingga selesainya tesis ini. Untuk saudara dan kerabat terkedekat yang juga memberikan perhatian dan 
doanya kepada saya. Saya juga mengucapkan terima kasih kepada dosen pembimbing dan penguji, pegawai dan seluruh civitas akademik Universitas Sumatera Utara yang memberi bimbingan, nasehat, serta dukungan untuk penyelesaian riset ini.

\section{DAFTAR PUSTAKA}

Ardianingtyas, M. \& Hersinta. (2018). Perlindungan Hukum Anak Penyandang Autisme. Diakses pada tanggal 18 Januari 2019, Dari Website: https://news.detik.com/kolom/4124744/pe rlindungan-hukum-anak-penvandangautisme/.

Book, C.L. (1980). Human Communication : Principles, Contexts and Skills. New York : St. Martin's Press.

Budyatna, M. \& Ganiem, L. (2011). Teori Komunikasi Antarpribadi. Jakarta: Kencana Prenada Media Group.

Danuatmaja, B. (2003). Terapi Anak Autis di Rumah. Jakarta : Puspa Swara.

Dokter Indonesia. (2015). 5 Kelebihan Anak Autis. Diakses pada tanggal 24 April 2018, Dari Website:

https://klinikautis.com/2015/09/06/4kelebihan-anak-autis/.

Handoyo. (2004). Autisma Petunjuk Praktis dan Pedoman Materi Mengajar Anak Normal,
Autis dan Perilaku Lain. Jakarta: Bina Ilmu Populer.

Hidayat, D.N. (2003). Paradigma dan Metodologi Penelitian Sosial Empirik Klasik. Jakarta: Departemen Ilmu Komunikasi FISIP UI.

Hikmat, M.M. (2011). Metode Penelitian dalam Perspektif Ilmu Komunikasi dan Sastra. Bandung: Graha Ilmu.

Kurniawan, N. (2009). Strategi Komunikasi Guru dalam Mendidik Murid Autisme, (Tesis, Universitas Sebelas Maret).

Marijani, L. (2003). Bunga Rampai, Seputar Autisme dan Permasalahannya. Jakarta : Putera Kembara Foundation.

Meranti, T. (2017). Psikologi Anak Autis. Yogyakarta: Familia.

Mirna, A. (2004). Merawat Balita Itu Mudah. Jakarta: Anak Prestasi Remaja.

Mulyana, D. (2003). Metodologi Penelitian Kualitatif Paradigma Baru Ilmu Komunikasi dan Ilmu Sosial Lainnya. Bandung: Remaja Rosdakarya. . (2005). Ilmu Komunikasi : Suatu Pengantar. Bandung: Remaja Rosdakarya.

Priherditya, E. (2016). Indonesia Masih 'Gelap' Tentang Autisme. Diakses pada tanggal 20 Februari 2018, Dari website: http://www.cnnindonesia.com/gavahidup/20160407160237-255122409/indonesia-masih-gelap-tentangautisme/.

Trisnadi, N.M. (2017). Analisis Proses Komunikasi Interpersonal Guru dan Anak Down Syndrome dalam Kegiatan Pembelajaran Life Skills, (Skripsi, Universitas Telkom). 